\title{
Dystocia Due to Fetal Arthrogryposis in a Non-Descript Sheep - A Case Report
}

\author{
C. T. Nikhade ${ }^{1 *}$, S. G. Deshmukh and R. P. Kolhe \\ Department of Animal Reproduction Gynaecology and Obstetrics, \\ Post Graduate Institute of Veterinary and Animal Sciences, Akola (MS), India \\ *Corresponding author
}

A B S T R A C T

\begin{tabular}{|l|}
\hline Ke y w o r d s \\
$\begin{array}{l}\text { In utero, Newborn } \\
\text { animals, Congenital } \\
\text { neurologic disorders }\end{array}$ \\
\hline Article Info \\
\hline $\begin{array}{l}\text { Accepted: } \\
15 \text { April } 2020 \\
\text { Available Online: } \\
10 \text { May } 2020\end{array}$ \\
\hline
\end{tabular}

\section{Keywords}

In utero, Newborn animals, Congenital

Accepted:

Available Online: 0 May 2020
A successful case of Dystocia due to fetal Arthrogroposis in non discript Sheep of a three year old multiparous nondescript sheep was presented with the history of full term gestation and water bag had ruptured one hour before with no further progress but the animal was straining. On vaginal examination, vaginal mucus membrane was pale, cervix was fully dilated and the fetal limbs were in birth canal. The presentation of fetus was posterior longitudinal, position was dorsosacral with flexed knee joint of right limb. Antibiotic and anti-inflammatory was continued for successive five days. The dam made uneventfull recovery.

\section{Introduction}

Arthrogryposis coupled with other skeletal deformities could be due to genetic and non genetic environmental factor. All types of arthrogryposis are associated with decreased fetal movement, which can usually be recognized by lack of normal movement in utero using real-time ultrasound studies. (Arthrogryposis in Calves Judith G. Hall, Angela Vincent, Chapter 7) Congenital and inherited abnormalities can result in birth deformities of newborn animals. Congenital disorders can be due to viral infections of the foetus or to ingestion of toxic plants by the dam at certain stages of gestation. The musculoskeletal system can also be affected by certain congenital neurologic disorders (Central Highland Veterinary Group).

Arthrogryposis (joints fixed in abnormal positions) is one such birth defect seen in cattle and sheep. Causes include infections of the dam with Akabane virus and Pestivirus (Mucosal disease in cattle and Border disease in sheep), as well as inherited defects. Arthrogryposis refers to the fixed flexion of one or more joints and wasting of muscles. 
Severely affected calves are usually born dead and often cause calving difficulties (dystocia), necessitating an embryotomy to deliver them. Arthrogryposis usually occurs at an early stage in an outbreak.

Arthrogryposis occurs mainly due to an alkaloid toxin that acts on the musculoskeletal system leading to permanent joint contracture in forelimbs and/or hind limbs (Shupe et al., 1967a). The affected limbs cannot be straightening out (Hartley et al., 1974; Sprake, 2015) and may include incorrect articular arrangement or rotational irregularity.

\section{Case history and observation}

A three year old multiparous nondescript sheep was presented with the history of full term gestation and water bag had ruptured one hour before with no further progress but the animal was straining (Fig. 1) and was trying to expel the fetus. She was dull and depressed with the temperature of $103{ }^{\circ} \mathrm{F}$. On vaginal examination, vaginal mucus membrane was pale, cervix was fully dilated and the fetal limbs were in birth canal. The presentation of fetus was posterior longitudinal, position was dorsosacral with flexed knee joint of right limb (Fig. 2).

\section{Treatment and discussion}

The treatment was started with $(25 \%$ Dextrose and normal saline $300 \mathrm{ml}$ ). Intravenous fluids and antihistamines (cadistin 2ml) intramuscularly. Afterwards with proper lubrication of vaginal passage the flexed right knee was corrected and pulled out with slight manual traction (Fig. 3). Further examination revealed absence of other fetus. The dam was given antibiotic (inj. Enrofloxacin $2.5-5 \mathrm{ml}$ ), analgesic (inj. Flunixin@1.1ml) intramuscularly and two intrauterine bolous (bolous Furea) were introduced. Antibiotic and anti-inflammatory was continued for successive five days. The dam made uneventfull recovery.

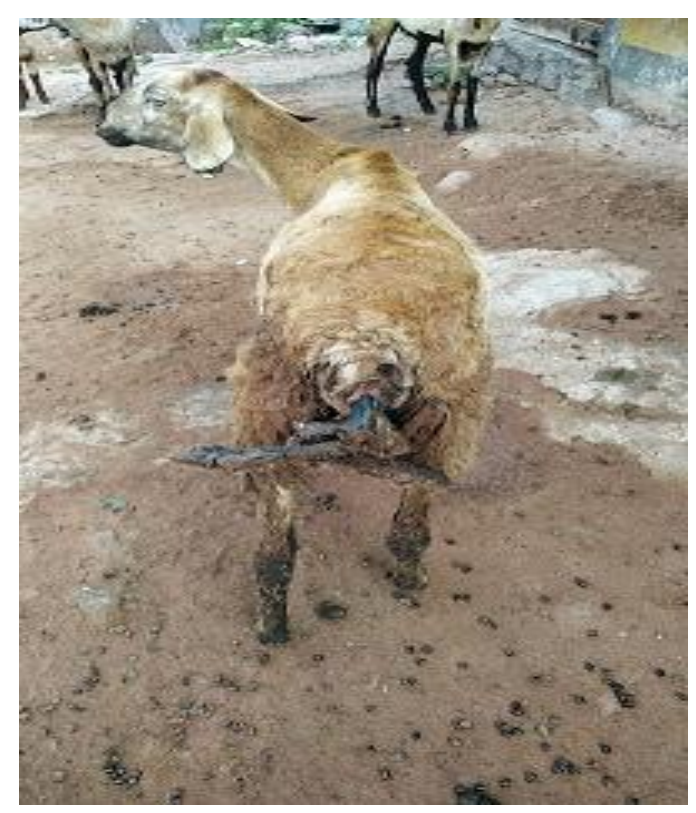




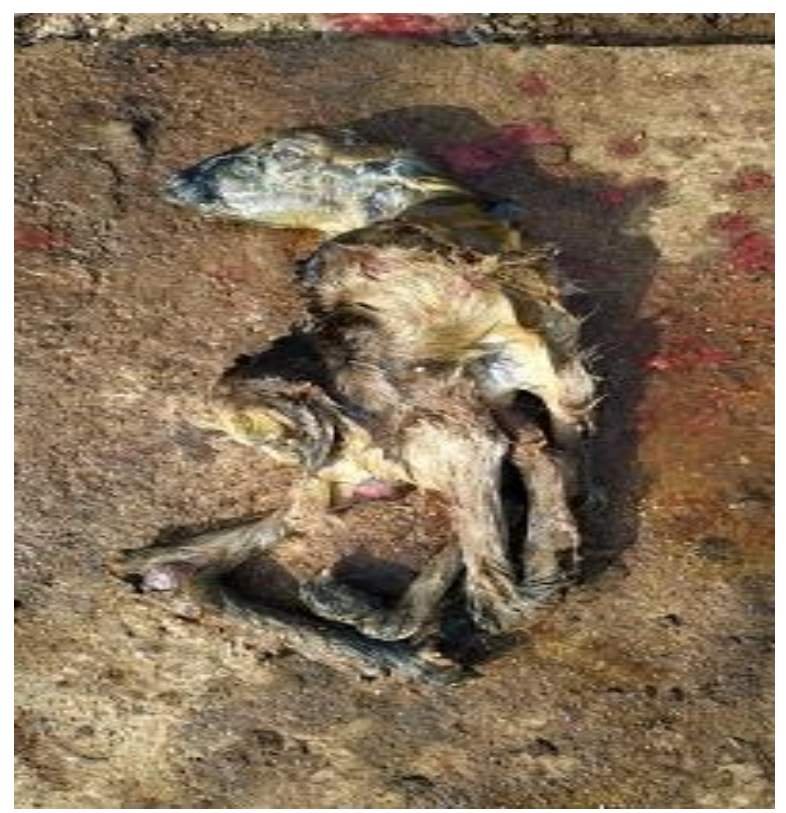

Fig.3 Fetal Arthrogryposis in Nondiscript Sheep

Arthrogryposis might be due to simple recessive gene which results in explusion of dead fetus with flexed limbs and wry neck in sheep and goat. (Robert, 1971)

\section{References}

Arthrogryposis in Calves Judith G. Hall, Angela Vincent, Chapter 7

Hartley, W. J. and Wanner, R. A. 1974. Bovine congenital arthrogryposis in New South Wales. Australian Veterinary Journal, 50(5): 185-188
Roberts, S.J. (1971) Veterinary Obstetrics and Genital Diseases, 2nd edn.CBS Publishers and Distributers. India. Pp 59

Shupe, J. L., Binns, W., James, L. F. and Keeler, R. F. 1967a. Lupine, a cause of crooked calf disease. Journal of the American Veterinary Medical Association, 151(2): 198-203.

Sprake, P. 2015. Diseases of the bones, joints and connective tissues. In: Smith, B.P. (ed), Large Animal Internal Medicine. St. Louis: Elsevier Mosby, pp. 1106

\section{How to cite this article:}

Nikhade, C. T., S. G. Deshmukh and Kolhe, R. P. 2020. Dystocia Due to Fetal Arthrogryposis in a Non-Descript Sheep - A Case Report. Int.J.Curr.Microbiol.App.Sci. 9(05): 2029-2031. doi: https://doi.org/10.20546/ijcmas.2020.905.230 